\title{
STRATEGI GURU MATEMATIKA DALAM MENGATASI KESULITAN BELAJAR BAGI SISWA KELAS X SMK NEGERI 2 SALATIGA
}

\author{
Rubai \\ rubeyabe369@gmail.com \\ Alumni Program Studi Pendidikan Matematika \\ FKIP - Universitas Kristen Satya Wacana \\ Tri Nova Hasti Yunianta \\ trinova.yunianta@staff.uksw.edu \\ Program Studi Pendidikan Matematika \\ FKIP - Universitas Kristen Satya Wacana \\ Wahyudi \\ yudhi@ staff.uksw.edu \\ Program Studi Pendidikan Matematika \\ FKIP - Universitas Kristen Satya Wacana
}

\begin{abstract}
ABSTRAK
Strategi guru matematika dalam mengatasi kesulitan belajar siswa menjadi judul dalam penelitian ini dengan alasan strategi yang dilakukan oleh guru matematika SMK Negeri 2 Salatiga berbeda dengan sekolah-sekolah lain dalam mengatasi kesulitan belajar yang dialami oleh siswa. Jenis penelitian ini adalah penelitian deskriptif kualitatif yang bertujuan untuk mengetahui deskripsi kesulitan belajar siswa dan mencari tahu strategi guru dalam mengatasi kesulitan belajar siswa pada pelajaran matematika. Subjek dalam penelitian ini adalah empat guru matematika SMK Negeri 2 Salatiga yang dipilih berdasarkan purposive sampling yang mana subjek tersebut memiliki beberapa macam strategi dalam mengatasi kesulitan belajar matematika, sehingga tujuan dalam penelitian ini dapat tercapai dengan mendeskripsikan strategi apa saja yang dilakukan guru tersebut dalam mengatasi kesulitan belajar siswa pada pelajaran matematika. Penelitian ini dilakukan dengan wawancara tidak terstruktur. Hasil dari penelitian ini menunjukkan bahwa kesulitan belajar siswa pada pelajaran matematika, berawal dari pola pikir siswa yang mana mereka selalu berpikir kerja dan meremehkan pelajaran umum. Berdasarkan hal tesebut mengakibatkan siswa malas, tidak semangat, sulit memahami materi yang disampaikan, mudah lupa, dan lambat dalam menerima pelajaran. Berdasarkan hal tersebut guru memiliki strategi untuk mengatasi kesulitan belajar siswa diantaranya adalah mengubah pemikiran siswa, membuat perbedaan tingkat (bobot) materi perjurusan, membuat ringkasan untuk siswa, menggunakan model pembelajaran tutor sebaya, melakukan pendekatan terhadap siswa, memberikan jam tambahan, memberikan motivasi, dan memberikan latihan soal mandiri.
\end{abstract}

Kata kunci: strategi guru, kesulitan belajar siswa, pelajaran matematika. 


\section{PENDAHULUAN}

Berdasarkan Peraturan Pemerintah Republik Indonesia No. 19 Tahun 2005 tentang Standar Nasional Pendidikan dikatakan bahwa standar nasional pendidikan adalah kriteria minimal tentang sistem pendidikan di seluruh wilayah hukum Negara Kesatuan Republik Indonesia (PP No. 19 Tahun 2005 Bab 1 Ayat 1). Standar Nasional Pendidikan ini memiliki fungsi sebagai dasar dalam perencanaan, pelaksanaan dan pengawasan pendidikan dalam mewujudkan pendidikan nasional yang bermutu. Selanjutnya, selain standar proses pendidikan adapun standar isi. Standar isi adalah ruang lingkup materi dan tingkat kompetensi yang dituangkan dalam kriteria tentang kompetensi tamatan, kompetensi bahan kaji, kompetensi mata pelajaran, dan silabus pembelajaran yang harus dipenuhi oleh peserta didik pada jenjang dan jenis pendidikan tertentu (PPNo. 19 Tahun 2005 Bab 1 Pasal 1 Ayat 5). Berdasarkan hal di atas maka proses pembelajaran untuk setiap mata pelajaran harus bervariasi, dan memenuhi standar. Proses pembelajaran pada setiap satuan pendidikan dasar dan menengah harus interaktif, inspiratif, menyenangkan, menantang, dan memotivasi peserta didik untuk aktif, serta memberikan ruang lingkup yang cukup untuk peserta didik, kreativitas, dan kemandirian sesuai dengan bakat, minat, dan perkembangan fisik serta psikologis peserta didik. Menurut Sanjaya (Ihsan, 2009: 27), strategi pembelajaran adalah suatu kegiatan pembelajaran yang harus dikerjakan guru dan siswa agar tujuan pembelajaran dapat dicapai secara efektif dan efisien. Trianto (2009: 145), mengemukakan bahwa terdapat beberapa strategi belajar yang dapat digunakan dan diajarkan yaitu: (1) strategi mengulang; (2) strategi elaborasi; (3) strategi organisasi; dan (4) strategi metakognis.
Berdasarkan hal di atas guru harus berupaya semaksimal mungkin untuk mewujudkan pendidikan yang bermutu bagi sekolah, namun hal tersebut tidak semudah yang dibayangkan. Terlebih pada pembelajaran matematika yang mana banyak siswa yang mengatakan sulit dan membosankan. Hal itu didukung dengan pendapat Abdurrahman (2010: 252) yang mengemukakan bahwa dari berbagai bidang studi yang diajarkan di sekolah, matematika merupakan bidang studi yang dianggap paling sulit oleh para siswa. Menurut Turmudi (2008: 1) menyatakan bahwa bertahun-tahun telah diupayakan agar matematika dapat dikuasai siswa dengan baik oleh ahli pendidikan matematika, namun hasilnya masih banyak siswa yang tidak menyukai matematika dari setiap kelasnya. Hal tersebut juga didukung oleh hasil wawancara dengan beberapa siswa kelas $\mathrm{X}$ Pemesinan SMK Negeri 2 Salatiga, siswa menganggap matematika merupakan pelajaran yang sulit dan membosankan.

Menurut National Joint Committee of Learning Disabilities (Abdurrahman, 2010: 7), berpendapat bahwa kesulitan belajar adalah istilah umum untuk berbagai jenis kesulitan dalam mendengarkan, bercakap-cakap, membaca, menulis, menalar, atau kemampuan dalam bidang studi matematika. Kondisi seperti itu bukan karena dari kecacatan fisik atau mental dan juga bukan karena faktor lingkungan, melainkan karena faktor dari dalam dirinya sendiri. Berdasarkan pendapat di atas dapat disimpulkan bahwa kesulitan belajar adalah hambatan dalam melakukan suatu hal atau dalam mencapai tujuan yang diinginkan dalam bidang matematika. Apabila mencapai tujuan yang diinginkan hasilnya tidak sesuai dengan apa yang telah diupayakan.

Moh.Surya (Suryawati, 2010) mengemukakan ciri-ciri siswa yang mengalami 
kesulitan dalam belajar yaitu ditunjukkan oleh: (1) hasil belajar yang rendah, di bawah rata-rata nilai yang dicapai oleh kelompoknya atau di bawah potensi yang dimilikinya; (2) hasil yang dicapai tidak seimbang dengan usaha yang telah dilakukan; (3) lambat dalam melakukan tugas-tugas kegiatan belajarnya dan selalu tertinggal dari kawan-kawannya dari waktu yang disediakan; (4) menunjukkan sikap-sikap yang tidak wajar; (5) menunjukkan perilaku yang berkelainan; dan (6) menunjukkan gejala emosional yang kurang wajar. Berdasarkan pendapat di atas dapat disimpulkan bahwa ciri- ciri siswa yang mengalami kesulitan belajar terlihat pada hasil belajar yang kurang memuaskan dan tidak seimbang dengan apa yang telah diusahakan.

Kesulitan belajar siswa menurut Brueckner dkk (Rachmadi, 2008) yaitu: (1) siswa yang mengalami kesulitan belajar disebabkan oleh faktor intelektual, umumnya kurang berhasil dalam menguasai konsep, prinsip, atau algoritma, walaupun telah berusaha mempelajarinya; dan (2) faktor kurang tepatnya guru mengelola pembelajaran dan menerapkan metodologi. Menurut Sutjihati Somantri (Suryawati, 2010) kesulitan belajar sebenarnya adalah suatu kondisi tertentu yang ditandai adanya hambatanhambatan dalam mencapai tujuan, sehingga memerlukan usaha yang lebih keras untuk menggapainya. Berdasarkan pendapat ahli di atas dapat disimpulkan bahwa kesulitan belajar siswa adalah siswa yang memiliki kemampuan berpikir kurang sehingga sulit untuk mencapai tujuan yang diinginkan, selain itu juga apabila di sekolah ditambah cara mengajar guru yang kurang tepat.

Berdasarkan indikasi dan faktor penyebab kesulitan belajar siswa maka guru perlu menggunakan strategi yang tepat untuk mengatasi masalah tersebut. Djamarah dan Zain (2010: 5) mengemukakan strategi dipa- hami sebagai garis besar haluan bertindak untuk mencapai sasaran yang telah ditentukan. Strategi mengatasi kesulitan belajar pada siswa yang dimaksudkan di atas yaitu usaha untuk tercapainya tujuan belajar yang diinginkan. Menurut Weener dan Senf (Soesilo, 2014), prosedur strategi mengatasi kesulitan belajar siswa yang dapat dilakukan berupa langkah-langkah sebagai berikut: (1) melakukan observasi kelas untuk melihat perilaku menyimpang peserta didik ketika mengikuti pembelajaran; (2) memeriksa penglihatan dan pendengaran peserta didik; (3) mewawancarai orang tua atau wali peserta didik untuk mengetahui kondisi keluarga yang mungkin menimbulkan kesulitan belajar; (4) memberikan tes diagnostik bidang kecakapan tertentu untuk mengetahui hakikat kesulitan belajar yang dialami peserta didik; (5) memberikan tes kemampuan intelegensi (IQ) khususnya kepada peserta didik yang diduga mengalami kesulitan belajar. Adapun menurut Dalyono (Suryawati, 2010), langkah yang perlu ditempuh dalam mengatasi kesulitan belajar pada siswa dapat dilakukan melalui enam tahap yaitu: 1) pengumpulan data; 2) pengolahan data; 3) diagnosis; 4) prognosis; 5) perlakuan; 6) evaluasi.

Berdasarkan hasil observasi awal serta berdasarkan pengalaman saat menjdi siswa di SMK Negeri 2 Salatiga, yang mana saat masih sekolah mengalami kesulitan belajar dan merasa guru matematika yang mengajarnya memiliki upaya atau strategi yang luar biasa untuk menciptakan siswa yang memiliki kemampuan kurang, dapat mengimbangi siswa yang memiliki kemampuan yang lebih. Guru tersebut memiliki strategi-strategi mengatasi kesulitan belajar yang kreatif. Pendekatan terhadap siswa yang mengalami kesulitan belajar dilakukan dengan cara pengamatan dan tindakan bertanya dengan keadaan siswa. Membuat ringkasan 
sendiri yang dibuat oleh guru tersebut dengan tujuan agar siswa dapat belajar materi selanjutnya dengan ringkasan tersebut dengan mudah. Ringkasan materi diberikan kepada siswa sebelum hari tatap muka. Pembuatan bobot materi yang berbeda-beda menyesuaikan per jurusan dengan maksud agar siswa yang memiliki kemampuan rendah tidak terlalu berat dengan materi yang diajarkan.

Berdasarkan masalah di atas, dipandang perlu melakukan penelitian tentang strategi guru matematika dalam mengatasi kesulitan belajar siswa. Penelitian ini diharapkan dapat menggambarkan dengan mendeskripsikan strategi guru dalam mengatasi kesulitan belajar siswa. Lebih khusus, agar guru dapat membantu siswa yang berkemampuan kurang dengan cara melihat strategi guru lain saat mengatasi kesulitan belajar siswa.

\section{METODE PENELITIAN}

Jenis penelitian yang digunakan dalam penelitian ini adalah deskripsi kualitatif. Menurut Sugiyono (2013: 15), metode penelitian kualitatif adalah metode penelitian yang berlandaskan pada filsafat postpositifsime, digunakan untuk meneliti pada kondisi objek yang alamiah (sebagai lawannya adalah eksperimen) dimana peneliti adalah sebagai instrumen kunci, pengambilan subjek sumber dan data dilakukan secara purposive, teknik pengumpulan data dilakukan dengan triangulasi (gabungan) analisis data kualitatif, dan hasil penelitian kualitatif lebih menekankan pada makna daripada generalisasi.

Penelitian ini dilakukan di SMK Negeri 2 Salatiga pada bulan Mei 2015. Subjek penelitian adalah empat guru matematika yang diantaranya adalah pak $\mathrm{H}$, Pak D, Bu A, dan Bu D. Pemilihan subjek tersebut menggunakan teknik purposive sampling yang mana menganut pada beberapa kriteria tertentu.
Teknik pengumpulan data pada penelitian ini menggunakan metode observasi, dokumentasi, dan wawancara. Menurut Sugiyono (2013: 308) menjelaskan bahwa dalam penelitian kualitatif, pengumpulan data dilakukan pada natural setting (kondisi yang alami), sumber data primer, dan teknik pengumpulan data lebih banyak pada observasi berperan serta (participant observation), wawancara mendalam, dan dokumentasi.

Wawancara yang digunakan dalam penelitian ini termasuk dalam kategori wawancara tidak terstruktur. Sugiyono (2013: 197) wawancara tidak terstruktur adalah wawancara yang bebas di mana peneliti tidak menggunakan pedoman wawancara yang telah tersusun secara sistematis dan lengkap untuk pengumpulan datanya. Pedoman wawancara yang digunakan hanya berupa garis-garis besar permasalahan yang akan ditanyakan. Metode ini bertujuan memperoleh informasi tertentu dari semua responden. Susunan pertanyaan dan susunan kata dalam setiap pertanyaan dapat diubah pada saat wawancara disesuaikan dengan kondisi dan kebutuhan saat wawancara. Peneliti menggunakan metode wawancara tidak tersetruktur dikarenakan dalam penelitian ini peneliti belum tahu secara rinci tentang strategi yag telah dilakukan oleh guru yang akan diteliti, sehingga peneliti menggunakan acuan menurut ahli tentang langkahlangkah dalam mengatasi kesulitan belajar. Jika langkah tersebut berbeda dengan apa yang telah dilakukan oleh guru tersebut maka peneliti dapat mengubah sewaktu proses wawancara dengan guru tersebut untuk mendapatkan tujuan yang diinginkan yaitu mengetahui strategi yang dilakukan guru matematka dalam mengatasi kesulitan belajar siswa. Adapun aspek kisi-kisi wawancara menurut Dalyono (Suryawati, 2010) mengemukakan langkah proses 
strategi mengatasi kesulitan belajar yaitu, pengumpula data, pengolahan data, diagnosis, prognosis, perlakuan, dan evaluasi. Kisi-kisi instrumen wawancara dapat dilihat pada Tabel 1.

Tabel 1 Kisi-kisi Instrumen Strategi Guru Matematika dalam Mengatasi Kesulitan Belajar Siswa

\begin{tabular}{|c|c|c|}
\hline No & Hal yang ditanya & Indikator \\
\hline 1 & Kesiapan guru & Persiapan mengajar guru \\
\hline \multirow[t]{2}{*}{2} & Kondisi kelas & Kondisi dan situasi kelas \\
\hline & & Penggunaan media \\
\hline \multirow[t]{2}{*}{3} & Pemahaman materi & Pengembangan materi \\
\hline & & Penyampaian materi \\
\hline \multirow{9}{*}{4} & \multirow{9}{*}{$\begin{array}{l}\text { Strategi mengatasi } \\
\text { kesulitan belajar }\end{array}$} & Faktor kesulitan belajar \\
\hline & & Kesulitan saat pembelajaran \\
\hline & & Strategi guru dalam mengatasi \\
\hline & & kesulitan belajar \\
\hline & & Jenis-jenis strategi guru mengatasi \\
\hline & & kesulitan belajar \\
\hline & & Varian strategi-strategi belajar \\
\hline & & Langkah-langkah mengatasi \\
\hline & & kesulitan belajar \\
\hline 5 & $\begin{array}{l}\text { Upaya mengenali } \\
\text { karakter siswa }\end{array}$ & Mengenali kepribadian siswa \\
\hline \multirow{2}{*}{6} & Evaluasi & Melakukan evaluasi \\
\hline & pembelajaran & Bentuk evaluasi \\
\hline 7 & $\begin{array}{l}\text { Bekerja sama dalam } \\
\text { membimbing siswa }\end{array}$ & $\begin{array}{l}\text { Bekerja sama dengan orang tua } \\
\text { dalam membimbing }\end{array}$ \\
\hline
\end{tabular}

Teknik keabsahan data yang dilakukan dalam penelitian ini menggunakan teknik triangulasi sumber. Menurut Sugiyono (2013: 373), triangulasi sumber adalah menguji kredibilitas data dilakukan dengan cara mengecek data yang telah diperoleh melalui beberapa sumber. Teknik ini dilakukan dengan pelaporan data yang telah diperoleh dari peneliti pada guru yang bersangkutan, bagian kurikulum sekolah, dan pada dosen pembimbing. Selain menggunakan kredibilitas data juga menggunakan bahan referensi. Menurut Sugiyono (2013: 375) bahan referensi adalah adanya pendukung untuk membuktikan data yang telah ditemukan oleh peneliti Bahan referensi yang digunakan dalam penelitian ini berupa rekaman hasil wawancara dan dokumentasi.

\section{HASIL PENELITIAN}

Berikut ini adalah hasil wawancara terhadap guru SMK Negeri 2 Salatiga dengan bebagai pertanyaan tentang Strategi Guru Matematika dalam Mengatasi Kesulitan Belajar Siswa.

\section{A. Subjek Pak H}

\section{Strategi mengatasi kesulitan belajar}

a. Faktor kesulitan dalam belajar dan kesulitan belajar siswa 
Faktor kesulitan belajar yang dialami siswa biasanya kurangnya motivasi diri. Kebanyakan siswa SMK sering mengesampingkan pelajaran umum karena mereka berpikiran jika lulus langsung bekerja dan yang dianggap penting hanya mata pelajaran yang mereka ambil atau jurusan mereka. Berdasakan hal tersebut maka mereka memiliki kesulitan belajar karena mereka sudah meremehkan pelajaran umum seperti halnya matematika. Siswa sering mengatakan saat pembelajaran berlangsung mereka bisa mengikuti pelajaran, namun jika di rumah lupa. Pak $\mathrm{H}$ memberikaan kunci kepada siswa untuk mata pelajaran matematika agar bisa. Kuncinya adalah latihan terus menerus karena matematika ilmu pasti dan jika malas dalam latihan atau tidak mau mencoba maka tidak akan bisa.

b. Strategi guru dalam mengatasi kesulitan belajar

Strategi untuk siswa yang kurang motivasi diri diberikan motivasi oleh guru agar mereka lebih semangat dalam belajar sehingga mereka menyenangi pelajaran umum dan menikmati apa yang sedang diajarkan. Pendekatan terhadap siswa yang memiliki kesulitan belajar, dengan keliling kelas, bertanya kodisi siswa dengan tujuan agar tau masalah yang dialami siswa sehingga guru lebih mudah dalam mengatasinya. Jika memang tidak memungkinkan di selesaikan di kelas maka guru memanggil siswa untuk menemui guru tersebut di kantornya, agar lebih leluasa menyelesaikan masalah kesulitan belajar siswa.

c. Langkah-langkah mengatasi kesulitan belajar

Langkah-langkah yang dilakukan tidak terstruktur jadi langkah guru hanya menyesuaikan saja jika ada siswa yang memiliki kesulitan belajar maka guru langsung menanganinya. Salah satu cara dengan mengumpulkan data dengan bertanya kondisi siswa. Berusaha mengetahui latar belakang yang dialami siswa. Guru memberikan tambahan jam, memberikan kesempatan untuk bertanya di ruang guru maupun di rumahnya, selain itu juga dengan pemberian motivasi siswa agar tambah semangat belajar.

\section{B. Subjek Pak D}

\section{Strategi mengatasi kesulitan belajar}

a. Faktor kesulitan dalam belajar dan kesulitan belajar siswa

Kesulitan yang dialami siswa yang masuk SMK disebabkan mereka kebanyakan beranggapan jika sekolah di SMK pasti untuk kerja jadi mereka hanya mementingkan pelajaran produktif atau pelajaran praktek saja dan pelajaran umum diremehkan, dengan begitu siswa akan mengalami kesulitan dalam pelajaran umum khususnya matematika karena pelajaran yang diremehkan akan terasa sulit. Salah satu cara dengan pemberian motivasi sangatlah penting untuk mengubah pemikiran mereka agar tidak berpikiran yang salah. Tujuannya agar siswa tidak hanya mementingkan pelajaran produktif saja namun seimbang dengan pelajaran umum, karena pelajaran umum sangat penting juga, seperti halnya matematika dalam kehidupan sehari-hari untuk kehidupan sekarang dan kelak nanti.

b. Strategi guru dalam mengatasi kesulitan belajar

Penggunan model pembelajaran tutor sebaya karena model tersebut cocok sekali, siswa lebih berani betukar pendapat dan mengutarakan hal-hal yag memang belum dipahami dengan temannya sendiri. Penggunaan metode tanya jawab, dengan mangajak siswa praktek langsung ke hal yang nyata seperti mengukur kolam tadi. Semakin 
banyak model yang diterapkan akan membuat siswa tidak bosan dengan materi yang diajarkan. Guru tersebut juga menggunakan strategi belajar mengulang dan elaborasi karena kemampaun siswa yang berbeda-beda maka guru perlu menggunakan strategi mengulang, namun juga mengingat waktu pembelajaran juga.

c. Langkah-langkah dalam mengatasi kesulitan belajar siswa

Langkah yang dilakukan untuk mengatasi siswa yang memiliki kesulitan belajar dengan cara langsung tanpa menggunakan langkah yang terstruktur, namun dilihat dari hasil wawancara guru tersebut memiliki langkah dengan mengidentfikasi siswa walaupun menurut jawaban Pak D tidak memiliki langkah yang terstruktur, tetapi sebenanya memilki langkah yang baik dengan mendekati siswa, guru tahu dengan keadaan siswa. Cara pertama dengan mengubah pemikiran siswa, memberikan motivasi kepada siswa. Penggunaan macammacam model pembelajaran yang bertujuan agar siswa lebih mudah menerima pelajaran yang diajarkan

\section{Subjek Bu A}

\section{Strategi mengatasi kesulitan belajar}

a. Faktor kesulitan dalam belajar dan kesulitan belajar siswa

Berdasarkan faktor malas untuk belajar mandiri karena saya menilai siswa yang masuk ke SMK N 2 memiliki kemampuan rata-rata ke atas. Sebenarnya mereka jika mau bersemangat dan latihan pasti bisa.

b. Strategi guru dalam mengatasi kesulitan belajar

Pemberian motivasi terhadap anak yang malas belajar mandiri penting sekali. Tujuannya agar mereka mau berkembang dengan mandiri tidak hanya menunggu ilmu dari apa yang telah diajarkan oleh gurunya. Selain itu guru tersebut juga menggunakan model pembelajaran tutor sebaya yang dianggap memang cocok meningkatkan hasil belajar siswa. Hal itu terbukti dengan hasil penelitian tindakan kelas yang dilakukan oleh guru tersebut. Tidak hanya model pembelajaran itu saja yang digunakan di dalam kegiatan pembelajaran namun bermacam-macam dengan tujuan agar siswa merasa senang dan tidak bosan dengan pelajaran yang diberikan.

c. Penggunaan jenis strategi mengulang, elaborasi, organisasi, dan metakognisi

Menggunakan strategi mengulang karena ada siswa yang masih bertanya tentang materi yang sudah di ajarkan sebelumnya. Hal seperti itu diterima oleh guru dan mau untuk mengulangnya. Mengaitkan materi yang yang sudah dipelajarinya dengan materi yang akan dipelajari. Memberikan kesempatan siswa untuk kreatif dengan penggunaan cara mereka sendiri untuk menyelesaikan permasalahan yang diberikan. Guru hanya memberikan masukan jika penyelesaian yang dikerjakan siswa menyimpang keluar dari penyelesaian yang seharusnya.

\section{Subjek Bu D}

\section{Strategi mengatasi kesulitan belajar}

a. Faktor kesulitan dalam belajar dan kesulitan belajar siswa

Faktor yang mempengaruhi kesulitan belajar siswa dapat dari sumber buku yang sekarang ini banyak salah cetak, bobot materi yang terlalu sulit, kalau untuk siswa SMK waktu juga mempengaruhi, karena jam praktek untuk produktif banyak sekali dan membuat siswa capek, sehingga menimbulkan kesulitan belajar siswa. Kurang konsentrasi, mengantuk. Kesulitan dalam memahami materi yang sedang dipelajarinya. 
b. Strategi guru dalam mengatasi kesulitan belajar

Salah satu strategi dalam membantu mengatasi kesulitan belajar siswa dengan membuat ringkasan materi yang kemudian diberikan kepada siswa untuk belajar sendiri, dengan ringkasan tersebut siswa akan lebih mudah karena ringkasan tersebut berdasarkan banyak literatur buku yang mana solusi yang diberikan yang paling mudah. Mengatasi siswa yang kurang konsentrasi dengan cara, memberikan motivasi kepada siswa, dan mengunakan model pembelajaran yang menyenangkan agar terbangun konsentrasi siswa, penggunaan model pembelajaran tutor sebaya yang mana memang efektif untuk siswa, model tersebut membuat siswa lebih santai.

c. Penggunaan jenis strategi mengulang, elaborasi, organisasi, dan metakognisi

Guru tersebut menggunakan jenis strategi mengulang, elaborasi dan juga metakognisi karena efektif. Pengulangan perlu sekali jika ada siswa yang belum paham dengan materi yang sudah dipelajari sebelumnya. Pengaitan materi yang sudah diajarkan dengan materi yang akan datang juga sangat perlu. Pemberian kesempatan kepada siswa untuk mengolah persoalan yang diberikan guru dengan caranya sendiri tidak harus dengan apa yang diberikan guru saja.

\section{PEMBAHASAN}

\section{Kesulitan Belajar Siswa}

Kesulitan yang dialami siswa pada umumnya memiliki faktor dari dalam diri mereka sendiri. Guru SMK Negeri 2 Salatiga menyampaikan bahwasannya siswa yang masuk ke SMK kebanyakan memiliki pemikiran kerja, sehingga pelajaran yang difokuskan oleh siswa hanya pelajaran kejuruan atau produktif saja, sedangkan pelajaran umum seperti matematika dan lainnya diremehkan, dengan begitu siswasiswa saat mengikuti pembelajaran matematika minatnya tidak maksimal. Kurang fokus dalam memperhatikan pembelajaran. Minat belajar mandiri juga kurang. Adapun siswa yang mengatakan jika saat pembelajaran paham dan setelah dirumah tidak bisa. Selain kesulitan belajar dari dalam diri siswa adapun juga dari sumber buku yang kurang, kebanyakan salah cetak, bobot materi buku yang terlalu sulit untuk siswa.

Konsentrasi siswa terganggu dengan hal tersebut menjadikan semangat dalam diri siswa tidak maksimal. Mengakibatkan siswa kesulitan dalam mengkuti perkembangan materi yang diajarkan oleh guru mapel. Sulitnya memahami materi yang sedang diajarkan. Lambat dalam menyelesaikan persoalan yang telah diberikan oleh guru.

\section{Strategi Guru dalam Mengatasi Kesulitan Belajar Siswa}

Berdasarkan hasil analisis yang telah dilakukan memberikan hasil beberapa strategi yang telah dilakukan guru SMK Negeri 2 Salatiga dalam mengatasi kesulitan belajar siswa sebagai berikut:

a. Mengubah PemikiranSiswa

Siswa yang masuk ke sekolah SMK kebanyakan memiliki pemikiran untuk bekerja saja, sehingga siswa hanya memikirkan pelajaran jurusan yang siswa ambil. Siswa meremehkan pelajaran umum, dengan begitu guru berusaha mengubah pemikiran siswa dengan memberikan peringatan betapa pentingnya pelajaran umum seperti halnya matematika. Pelajaran matematika bukan hanya untuk sampingan saja namun untuk kehidupan sehari-hari juga penting seperti dalam berbelanja, membuat bangunan, dalam berbisnis, dan lainnya. 


\section{b. Membuat Perbedaan Tingkat (bobot) Materi Perjurusan}

Pembuatan perbedaan tingkat materi yang dilakukan oleh Pak D dengan alasan kemampuan siswa perjurusan pasti berbeda jika dilakukan dengan bobot yang sama maka siswa yang memiliki kemampuan di bawah rata-rata akan kesulitan dalam memahami dan menyelasaikan persoalan yang diberikan oleh guru. Contoh sederhana bobot yang dibuat oleh guru tersebut spserti, apabila kelas A diberikan soal $3 \times 4+5-2$ maka kelas B hanya diberikan $3 \times 4$ nya saja. Tujuannya agar siswa yang memiliki kemampuan kurang tidak berkesulitan mengikuti pelajaran. Guru tersebut juga senang jika siswa yang memiliki kemampuan sekurang apapun akan merasa bisa dengan apa yang telah diajarkan.

\section{c. Membuat Ringkasan untuk Siswa}

Guru memberikan ringkasan materi pembelajaran sebelum proses pembelajaran dimualai atau sebelum pertemuan di kelas. Tujuan guru agar siswa lebih mudah dalam mempelajari materi yang akan diberikan. Siswa memiliki pandangan materi selanjutnya yang akan dibahas oleh guru sehingga memudahkan guru untuk menerangkan materi. Ringkasan yang dibuat tidak hanya dari buku pegangan siswa namun menggunakan literatur buku lain yang materinya dianggap mudah untuk dicerna oleh siswa.

\section{d. Menggunaan Model Pembelajaran Tutor} Sebaya

Penggunaan model pembelajaran tutor sebaya dianggap oleh guru SMK sangat efektif, hal itu juga dibuktikan dari hasil penelitian oleh $\mathrm{Bu} \mathrm{A}$ yang mana hasilnya meningkatkan hasil belajar siswa. Model tersebut membuat siswa lebih santai, dan lebih berani dalam bertukar pikiran, mengutarakan pendapat siswa, dan siswa tidak ragu- ragu dalam mengajukan pertanyaan yang dianggap kurang bisa karena dengan temannya sendiri berbeda jika berhadapan dengan guru langsung.

e. Pendekatan Terhadap Siswa

Pendekatan siswa dilakukan secara keseluruhan dan individu. Secara keseluruhan guru melihat dengan cara siswa belajar kelompok, diskusi bersama, dan melihat dari nilai siswa. Secara individu guru keliling bertanya dengan siswa yang dianggap memiliki masalah kesulitan belajar. Guru mengajak diskusi pada waktu jam pelajaran maupun di luar pelajaran. Mengajak curhat dengan siswa dengan tujuan agar lebih mudah mengetahui permasalahan siswa dan memberikan masukan untuk menyelesaikan masalah yang dialami.

f. Memberikan Jam Tambahan

Siswa yang memiliki masalah kesulitan belajar guru memberikan tambahan jam pelajaran. Hal ini dilakukan di kelas, di kantor, dan juga di rumah guru mapel. Jam tambahan yang dilakukan di kelas untuk keseluruhan siwa dan dbantu oleh siswa yang memiliki kemampuan di atas rata-rata dari teman lainnya. Jam pelajaran di kantor untuk memberikan kesempatan kepada siswa yang merasa memiliki kesulitan dengan materi yang diajarkan dengan kesadaran mereka sendiri. Tidak jauh berbeda dengan jam pelajaran yang dilakukan di rumah guru tersebut.

\section{g. Memberikan Motivasi}

Pemberian motivasi untuk siswa yang memiliki kesulitan belajar dari faktor dalam diri siswa, guru memberikan motivasi dengan gambaran betapa besar usaha yang dilakukan oleh orang tua kalian untuk menyekolahkan dengan tujuan kalian menjadi siswa yang pintar dan memiliki prestasi. Balasan yang orang tua minta bukan apa-apa hanya nilai 
yang bagus dan prestasi yang kalian capai. Orang tua akan senang jika mendengar kalian mendapat pestasi dan nilai yang bagus. Motivasi untuk siswa yang memiliki masalah dengan keluarga guru memberikan semangat agar siswa tidak memikirkan masalah yang dialami.

h. Memberikan Latihan Soal Mandiri

Pemberian soal untuk siswa di rumah atau pekerjaan rumah tujuannya agar siswa mau belajar mandiri. Menanggulangi kemalasan siswa dan agar siswa mau berlatih. Selain itu juga untuk mengajarkan tanggung jawab untuk siswa. Pemberian PR untuk siswa secara langsung untuk mengasah daya ingat siswa agar tidak langsung lupa dengan materi yang baru saja diajarkan oleh guru tersebut.

\section{PENUTUP}

Berdasarkan hasil dan pembahasan dalam penelitian ini terdapat dua hal penting mengenai kesulitan belajar siswa dan strategi guru dalam mengatasi kesulitan belajar siswa. Kesulitan belajar yang dialami siswa antara lain: 1) berasal dari dalam diri siswa sendiri yang kebanyaakan memiliki pemikiran setelah lulus dari SMK langsung kerja sehingga siswa hanya fokus pada pelajaran produktif saja; 2) sumber buku yang kurang; dan 3) kebanyakan salah cetak (bobot materi buku yang terlalu sulit untuk siswa). Beberapa hal tersebut mengakibatkan siswa kesulitan dalam mengikuti perkembangan materi yang diajarkan oleh guru mapel, sulit memahami materi yang sedang diajarkan dan lambat dalam menyelesaikan persoalan yang telah diberikan oleh guru. Berdasarkan masalah tersebut, guru SMK Negeri 2 Salatiga memiliki strategi dalam mengatasi kesulitan belajar siswa diantaranya: 1) mengubah pemikiran siswa; 2) membuat perbedaan tingkat (bobot) materi perjurusan; 3) membuat ringkasan untuk siswa; 4) menggunakan model pembelajaran tutor sebaya; 5) melaku- kan pendekatan terhadap siswa; 6) memberikan jam tambahan; dan 7) memberikan motivasi.

Berdasarkan hal-hal yang telah ditemukan, perlu bagi guru membuat strategi khusus untuk mengatasi kesulitan belajar siswa secara terstruktur seperti langkah yang diungkapkan oleh Dalyono (Suryawati) agar lebih mudah dalam penanganannya. Perlu fasilitas pendukung pembelajaran yang berbasis IT sehingga mempermudah siswa maupun guru dalam pembelajaran matematika. Selain itu untuk penelitian selanjutnya agar menambahkan subjek penelitian lebih dari satu sekolahan agar mendapatkan hasil yang lebih baik.

\section{DAFTAR PUSTAKA}

Abdurrahman, M. 2010. Pendidikan Bagi Anak Berkesulitan Belajar. Jakarta: Rineka Cipta.

Djamarah, S.B dan Zain, Aswan. 2010. Strategi Belajar Mengajar. Jakarta: Rineka Cipta.

Ihsan, Nurul. 2009. Strategi Guru Dalam Mengatasi Kesulitan Belajar Siswa Kelas IX IPS 3 Pada Mata Pelajaran Ekonomi di MAN Malang 1 Tlogomas. Skripsi. Malang: Program Studi Pendidikan Ekonomi. UIN.

Peraturan Pemerintah Republik Indonesia. 2005. Peraturan Pemerintah Nomor 19 Tahun 2005 tentang Standar Nasional Pendidikan.

Rachmadi, W. 2008. Diagnosis Kesulitan Belajar Matematika SMP dan Alternatif Proses Remidinya. Yogyakarta: Pusat Pengembangan dan Pemberdayaan Pendidikan dan Tenaga Kependidikan Matematika.

Sugiyono. 2013. Metode Penelitian Pendidikan Pendekatan Kuantitatif, Kualitatif, dan $R \& D$. Bandung: Alfabeta. 
Suryawati, Titik. 2010. Upaya Guru Dalam Mengatasi Kesulitan Belajar Siswa Di MI Nurul Islam Mirigambar Sumbergempol Tulungagung. Skripsi. Tulungagung: Pendidikan Agama Islam. STAIN.
Trianto. 2009. Mendesain Model Pembelajaran Inovatif-Progesif. Surabaya: PT Fajar Interpratama.

Turmudi. 2008. Landasan Filsafat dan Teori Pembelajaran Matematika (Berparadigma Eksploratif dan Investigatif). Jakarta: Leuser Cipta Pustaka. 